\title{
Participatory Guarantee Systems (PGS) in Mexico: a theoretic ideal or everyday practice?
}

\author{
Sonja Kaufmann ${ }^{1} \cdot$ Christian R. Vogl $^{1}$
}

Accepted: 22 November 2017 / Published online: 19 December 2017

(C) The Author(s) 2017. This article is an open access publication

\begin{abstract}
Third-party certification (TPC), the most common organic certification system, has faced growing criticism in recent years. This has led to the development of alternative certification systems, most of which can be classed as Participatory Guarantee Systems (PGS). PGS have been promoted as a more suitable, cheaper and less bureaucratic alternative to TPC for local markets and are associated with additional benefits such as empowering smallholder farmers, facilitating farmer-to-farmer learning and enhancing food security and sovereignty. PGS have spread rapidly in the past few years, but studies suggest that they are facing numerous challenges that, if not addressed, may jeopardise these benefits. Using the example of three Mexican PGS initiatives, this paper explores the main challenges faced by PGS, specifically those predominantly found in producer-run PGS initiatives. Based on producer and consumer surveys, semi-structured and informal interviews, and participant and non-participant observation, the key challenges that emerged were continuous implementation of the certification process, time constraints, personal conflicts and conflict avoidance. The paper further argues that the requirements for PGS recognition under the Mexican Law for Organic Products may also threaten the continued existence of PGS and suggests that mechanisms for managing conflicts, incentivising PGS participation and mitigating opportunity costs are key if PGS are to continue to develop.
\end{abstract}

Keywords Participatory Guarantee Systems $\cdot$ Mexico $\cdot$ Organic certification · Organic agriculture $\cdot$ Farmers' markets

\begin{tabular}{|c|c|}
\hline \multicolumn{2}{|c|}{ Abbreviations } \\
\hline AFNs & Alternative Food Networks \\
\hline CPR & Common-pool resources \\
\hline IFOAM & $\begin{array}{l}\text { International Federation of Organic Agriculture } \\
\text { Movements }\end{array}$ \\
\hline LFS & Local Food Systems \\
\hline LPO & $\begin{array}{l}\text { Ley de Productos Orgánicos (Law for Organic } \\
\text { Products) }\end{array}$ \\
\hline NOP & National Organic Program \\
\hline PCC & $\begin{array}{l}\text { Participatory Certification Committee (comité } \\
\text { de certificación participativa) }\end{array}$ \\
\hline PGS & Participatory Guarantee Systems \\
\hline TPC & Third-Party Certification \\
\hline
\end{tabular}

Christian R. Vogl

christian.vogl@boku.ac.at

Sonja Kaufmann

kaufmann_sonja@hotmail.com

1 Department of Sustainable Agricultural Systems, University of Natural Resources and Life Sciences Vienna, Gregor-Mendel-Str. 33, 1180 Vienna, Austria

\section{Introduction}

Since the early 1990s, the market for organic products has grown rapidly, accompanied by a shift from an organic certification system based on peer review to a system of third-party certification (TPC) (Fouilleux and Loconto 2017; Sligh and Cierpka 2007). TPC implies a high degree of standardisation in inspection, certification and related processes. This high degree of standardisation is considered necessary to inhibit fraud, guarantee fair competition and ensure the integrity of organic products (Källander 2008; Meirelles 2003). TPC is the most common organic certification system and is often viewed as the most reliable form of conformity assessment (Hatanaka et al. 2005; Padel et al. 2010). In recent years, however, TPC has faced increasing criticism.

Due to the high costs of certification and documentation requirements, small-scale farmers often find it hard to achieve TPC and access organic markets, especially in the Global South (Cáceres 2005; Fouilleux and Loconto 2017; Nelson et al. 2016). The strict separation of extension services and certification demanded from TPC by ISO 17065 
makes fulfilling the paperwork requirements even more burdensome (Cáceres 2005). Due to its high degree of standardisation, TPC is deemed by some to be incapable of accounting for the diverse economic, ecological and sociocultural environments of organic farming (Fouilleux and Loconto 2017; Källander 2008; Meirelles 2003) or allowing the adaptation of organic production systems to local contexts, a core element of organic farming (Raynolds 2004; Vogl et al. 2005). TPC is also associated with the so-called "conventionalization" of organic farming (Darnhofer 2006; Nelson et al. 2010). TPC's focus on outcome and the provision of guarantees through annual visits by external inspectors are considered contradictory to farmers' self-determination and empowerment, an impediment to their political involvement and an encouragement of the concentration of power in the hands of TPC bodies (Andrade 2015; Beck and Walgenbach 2003; Källander 2008; Meirelles 2003; Schulze et al. 2006; Velleda Caldas et al. 2014). As TPC bodies are often located in the Global North, the implementation of TPC in the Global South is perceived by some actors as imposing standards from the Global North on the Global South (Home et al. 2017; Nelson et al. 2016).

Motivated by these criticisms, alternatives have been developed since the 1990s that aim to provide farmers with a more locally adapted certification scheme for domestic markets. Most of these alternatives can be classed as Participatory Guarantee Systems (PGS) (Nelson et al. 2010, 2016; Raynolds 2004; Vogl and Axmann 2016).

The International Federation of Organic Agriculture Movements (IFOAM) defines PGS as "locally focused quality assurance systems. They certify producers based on active participation of stakeholders and are built on a foundation of trust, social networks and knowledge exchange" (IFOAM 2008, p. 1). PGS have been promoted as locally organised social systems to ensure that organic product claims are met. PGS are based on the active participation of producers, consumers and other stakeholders engaged throughout the organic value chain. PGS are said to foster learning processes and knowledge exchange and to be built on a foundation of trust based on the direct engagement of actors (Bouagnimbeck 2014; IFOAM 2007; May 2008). It is argued that this engagement is positively linked to strong relationships among participating actors and social cohesion (Home et al. 2017), which facilitates social control, respect of rules and trust among PGS members (Zanasi et al. 2009).

PGS are also promoted as less costly and less bureaucratic than TPC (Nelson et al. 2010; Sacchi et al. 2015), more flexible and better adapted to the realities of smallholder farmers (Nelson et al. 2016), and advocated as tools to foster their inclusion in organic production (Coscarello and Rodríguez-Labajos 2015). They are considered as a means for empowering smallholders and local stakeholders (Boza Martínez 2013; Nelson et al. 2016), facilitating market access and strengthening local markets (IFOAM 2007; Källander 2008). PGS have also been promoted as mechanisms to facilitate sustainable community development (IFOAM 2007; Nelson et al. 2010), foster knowledge creation and farmer-to-farmer knowledge exchange (Home et al. 2017; Kirchner 2014), enhance farming communities' livelihoods (IFOAM 2007), support family agriculture (Coscarello and Rodríguez-Labajos 2015) and increase food security (Home and Nelson 2015; Nelson et al. 2010) and food sovereignty (Nelson et al. 2016).

PGS have been situated within the "beyond organic" movement and pictured as social organisations that redistribute power to the local level (Nelson et al. 2010). They have been framed as local institutions for collective action to govern local food systems (LFS) (Nelson et al. 2016) and as a key element in building alternative food networks (AFNs) in the Global South (Bellante 2017). Applying the definition of AFNs of DuPuis and Goodman (2005), which emphasises the opposition to conventional food system dynamics as their distinctive criterion, and the definition of Morgan et al. (2006), which views AFNs as food systems that reallocate value in contrast to the dynamics of conventional commodity production, re-establish trust between producers and consumers and allow for different market governance mechanisms, PGS fit within this rationale. Considering the ideal of consumer involvement in PGS (IFOAM 2007; May 2008), and the role of consumers in initiating and organising some PGS (Bellante 2017; Fonseca 2004), PGS can even be framed as civic food networks that are more citizen-driven and as "new types of AFNs" (Renting et al. 2012, p. 290).

IFOAM records 133 operational PGS initiatives and 100 PGS under development in 72 countries, with a total number of 109136 producers and processors engaged and 46865 certified (IFOAM 2016a, b). Although PGS have developed rapidly in recent years, they are facing various challenges, stemming in part from the key elements found in this type of certification (Källander 2008; May 2008).

Challenges include the lack of legal recognition as an organic certification scheme (Home et al. 2017; Meirelles 2003; Nelson et al. 2010), ${ }^{1}$ sustainable financing of the PGS (Fonseca 2004; Nelson et al. 2010), biases in decision-making and personal conflicts (Home et al. 2017; Nelson et al. 2010). There are also difficulties in securing the sufficient participation of producers and consumers (Bellante 2017; Home et al. 2017; Nelson et al. 2010, 2016) due to time constraints, the long distances involved, a lack of transportation or a perceived lack of competence to carry out certification (Bellante 2017; Bouagnimbeck 2014; Fonseca 2004; Home

\footnotetext{
1 Except for a few countries (e.g., Brazil, Bolivia, Costa Rica and Mexico), PGS have not yet been legally recognised as an alternative to TPC (for domestic markets) (May 2008; Nelson et al. 2010).
} 
et al. 2017; Nelson et al. 2010, 2016). Lack of participation is associated with a lack of trust in and credibility of the PGS and hampers knowledge exchange, equal sharing of responsibilities and the full empowerment of farmers (Bouagnimbeck 2014; Kirchner 2014; Nelson et al. 2010).

Research on PGS has just started and academic literature on PGS is still limited (for exceptions see Bellante 2017, Home et al. 2017, Nelson et al. 2010, Nelson et al. 2016, Sacchi et al. 2015 and Zanasi et al. 2009). Many phenomena linked to PGS have not yet been studied on a robust empirical basis. Although several authors have highlighted the above-mentioned challenges, most of them still have a romanticised view of PGS, at times even over-emphasising their strengths. It is argued that this view represents a major threat to further PGS development as it obscures the challenges they are facing and the potential pitfalls of PGS, preventing their proliferation and jeopardising their potential benefits (Källander 2008; May 2008). Challenges therefore need to be clearly addressed if PGS are to achieve their full potential. Therefore, the aim of this paper is to address the research gap on the challenges involved with PGS. Drawing on the case of Mexican PGS, this paper explores the main challenges experienced in the selected Mexican PGS based on empirical evidence. As the PGS initiatives were found to be operated exclusively by producers, it is relevant to emphasise the challenges they face, particularly in PGS initiatives that are run exclusively by producers. Being one of only a few countries in which PGS are legally recognised, Mexico's experience with legal PGS endorsement and the related consequences experienced at grassroots level could be of benefit to other countries interested in encouraging the use of PGS (Home et al. 2017), hence this will be emphasised in the final section of these findings.

\section{PGS in Mexico and the network of local organic markets}

In Mexico, PGS have developed from and are adopted in local organic markets, based on certification committees formed at market level (Escalona 2009; Nelson et al. 2010). Since the first markets were established (1996 and 2003), local organic markets have become increasingly popular throughout the country (Nelson et al. 2010). These markets are not solely points of sales for organic products but rather "seek to support local food security through the provision of safe food at fair prices, improve local ecology by encouraging organic production, build a sense of community through direct sale and cultural activities, and educate the public about environmental and social issues related to food systems" (Nelson et al. 2010, p. 231). This definition mirrors different rationales underlying PGS adoption, the diverse dimensions of PGS and some elements promoted as inherent to local food systems, and alternative and civic food networks (DuPuis and Goodman 2005; Morgan et al. 2006; Papaoikonomou and Ginieis 2017; Renting et al. 2012).

In 2004, the four pioneering markets established the Mexican Network of Local Organic Markets (hereinafter referred to as the Network). Run out of the University of Chapingo, the Network has played a leading role in fostering the development of new markets and promoting PGS. The number of member markets has steadily increased (Nelson et al. 2010; Nigh and González Cabañas 2015), with Nelson et al. (2016) reporting around 20 markets across 15 Mexican states. With the necessary financial means provided by a Canadian NGO, the Network has facilitated PGS adoption and development across member markets. It has run national exchange meetings and training for local PGS committees and provided PGS manuals. Owing to fundamental contributions by the Network, PGS were endorsed in 2006 as a legal alternative to TPC for the domestic market in the Mexican Law for Organic Products (LPO) (Nelson et al. 2010).

Although the Network's member markets have adopted common patterns of PGS, the exact operation of the PGS varies across markets. The markets have themselves been undergoing diverse development regarding PGS implementation, including gaps across and within markets (Escalona 2009; IFOAM 2013; Nelson et al. 2010, 2016). When funding by the Canadian NGO ceased in 2011, the Network faced increasing difficulties in maintaining its services. It was uncertain how it would continue its work (IFOAM 2013; Nelson et al. 2016) and day-to-day operations became challenging for some member markets (IFOAM 2013).

This raises the question of how markets and their PGS have developed since then. Revisiting three of the Network's member markets, this article provides a follow-up on PGS adoption in Mexico. Drawing on data collected from producers, consumers and other actors engaged in these markets, the paper assesses the current situation of PGS implementation and identifies related challenges and influencing factors. In doing so, we address the primary aim of this paper, which is to focus on the challenges faced by participants. Furthermore, this approach identifies options for addressing these challenges and points out key factors for achieving PGS sustainability.

\section{Research methods}

The empirical data presented in this paper were collected between September 2015 and March 2016 in the Chapingo organic market, the Tlaxcala alternative market and the "El Pochote Xochimilco" alternative market in Oaxaca. Surveys were conducted with market producers and consumers using closed-ended and open-ended questions. Qualitative 
Table 1 Research methods applied in case study markets

\begin{tabular}{|c|c|c|c|c|}
\hline $\begin{array}{l}\text { Data collection } \\
\text { method }\end{array}$ & Type of interview partner & $\begin{array}{l}\text { Number of participants } \\
\text { per market } A / B / C\end{array}$ & $\begin{array}{l}\text { Sampling strategy } \\
\text { (Bernard 2011) }\end{array}$ & Type of analysis \\
\hline \multirow[t]{2}{*}{ Surveys } & $\begin{array}{l}\text { Producers }(\mathrm{n}) \\
\mathrm{n} \text { in } \% \text { of number of all stands selling food products }\end{array}$ & $\begin{array}{l}22 / 15 / 23 \\
96 \% / 79 \% / 62 \%\end{array}$ & Convenience & $\begin{array}{l}\text { Descriptive } \\
\text { statistics and } \\
\text { non-paramet- } \\
\text { ric tests }\end{array}$ \\
\hline & Consumers (n) & $21 / 20 / 20$ & Convenience & $\begin{array}{l}\text { Descriptive } \\
\text { statistics and } \\
\text { non-paramet- } \\
\text { ric tests }\end{array}$ \\
\hline \multirow[t]{2}{*}{ Interviews } & Market coordinators (producers) & $1 / 1 / 1$ & Purposive & Content analysis \\
\hline & Members of certification committee (producers) & $0 / 1 / 0$ & Purposive & Content analysis \\
\hline
\end{tabular}

$A$ Chapingo, $B$ Tlaxcala, $C$ Oaxaca

interviews with producers in key positions in the market and PGS organisation were also conducted (Table 1).

Other key informants concerned with PGS were interviewed using a semi-structured or informal interview format (Bernard 2011). Participant and non-participant observation and information from informal interviews and conversations conducted during market days, General Assembly meetings and some farm visits, and some key documents from the market (e.g., internal market or PGS regulation) complemented the obtained data (Bernard 2011; Puri 2011; Yin 1994).

Eight other local markets in different stages of PGS development and adoption were visited and informal conversations and informal interviews (Bernard 2011) held with producers, consumers and coordinators.

Interviews were recorded using a digital voice recorder and transcribed or recorded by note-taking. Observational protocols were prepared based on notes and jottings made during the observation (Bernard 2011). Transcripts, protocols and documents were processed using a combination of deductive and inductive coding strategies and content analysis, with survey data analysed using IBM SPSS Statistics 21 (IBM). Differences between markets were tested for statistical significance using the Kruskal-Wallis $\mathrm{H}$ and Mann-Whitney U tests, applying a significance level of 5\% and using Bonferroni-corrected $\mathrm{p}$ values for comparing two markets (Bühl 2016; Janssen and Laatz 2010). Exact tests were used due to small sample sizes and the number of ties (Bühl 2016). Qualitative survey data were coded, applying in vivo coding and descriptive coding for quantitative analysis (Saldaña 2013).

Studies comprehensively treating issues found to be key in further PGS development (adoption of mechanisms to manage conflicts and account for opportunity costs of participation inter alia) have not yet been published. We argue that experiences from the management of common-pool resources (CPR) (Ostrom 2007, 2015) and environmental conflict resolution (O'Leary and Bingham 2003) can inform researchers and practitioners engaged with PGS, help identify solutions and suggest new action strategies. To interpret the results, reference is made to studies on community-based management of protected forests (Idrissou et al. 2011) and marine areas (Gurney et al. 2016), community forest governance (Barnes and Van Laerhoven 2013; Black and Watson 2006; Ravikumar et al. 2013; Van Laerhoven and Andersson 2013), reforestation of communal land (d'Adda 2011), joint water management (Black and Watson 2006) and common property grazing resources (Vedeld 2000; Vollan 2008), in addition to the concept of social cohesion applied as a theoretical framework in some of these studies (Kawachi and Berkman 2014; Kearns and Forrest 2000). Although not perfectly comparable, following Nelson et al. (2016, p. 375), who argue that "the integrity of Mexico's local organic markets can be considered a common-pool resource", it was found that some analogical conclusions could be expanded to the PGS context.

\section{Field sites}

The three case study markets were in the states of Mexico (Chapingo), Tlaxcala (Tlaxcala City) and Oaxaca (Oaxaca City).

\section{Chapingo organic market (A)}

The Chapingo Organic Market was founded in 2003 under the leadership of actors affiliated with the University of Chapingo. As one of the founding markets of the Network, it has taken a leading position in PGS development in Mexican organic markets. The bonds it has maintained with the university have fundamentally facilitated market and PGS development (Nelson et al. 2010). Until 2010, the market had financial support from university projects. The founding 
group, which included university affiliates, coordinated all the market activities, including certification (internal regulation Chapingo 2016). When financing stopped, market and PGS management was increasingly taken over by producers (Resp.8/I1). ${ }^{2}$ Since its inauguration, the market had been held in a building owned and provided free of charge by the university. ${ }^{3}$ At the time of data collection, the market had 28 stands managed by approximately 23 producer families. ${ }^{4}$

\section{Tlaxcala alternative market (B)}

The Tlaxcala Alternative Market was founded in 2005 by local NGOs that had been training producers in agroecology for several years, by producers looking for a way to sell surpluses from subsistence farming, and by one consumer (Resp.2/I1). From the outset the market was linked to the Network (Resp.8/I4). At the time of data collection, the market was held on a public square and comprised 24 stands managed by 24 producer families.

\section{El Pochote Xochimilco alternative market, Oaxaca City (C)}

The "El Pochote Xochimilco" Alternative Market was founded in 2010 (Resp.8/I4; Resp.4/I1). The development of the market's PGS had been supported by an agricultural engineer who was working for a TPC body (Resp.4/ I1; Resp.8/I4). The market joined the Network in 2010. At the time of data collection, the market was held in an open square provided by the parish and had approximately 59 stands managed by 59 families.

The eight other markets visited were in Oaxaca City (2), Mexico City (5) and San Luis Potosi (1).

\footnotetext{
$\overline{2}$ To ensure the anonymity of respondents, abbreviations will be used throughout the paper; for more information see the list of respondents in the Appendix.

3 At the time data collection ended, the University of Chapingo had restarted its close cooperation with the market. University affiliates resumed market and PGS coordination. Any ensuing changes will be indicated only if considered relevant for presented results.

4 The term "producer" is used to refer to individuals or families who participate as vendors at the weekly market, including processors and vendors who sell products that they have not produced or processed themselves.
}

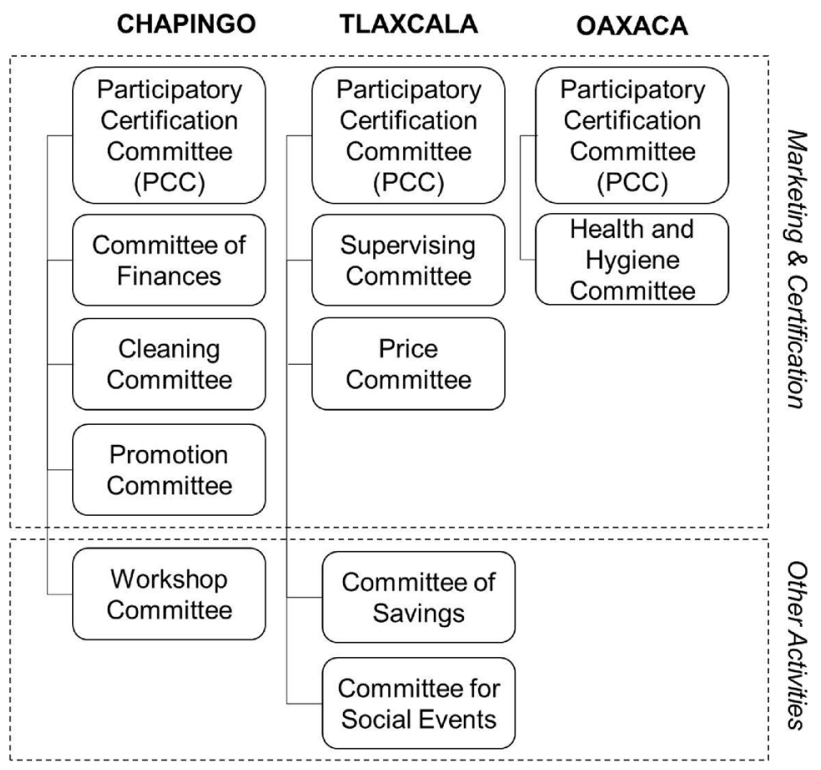

Fig. 1 Working committees other than the Participatory Certification Committees (PCC) formed in the case study markets (internal regulation Chapingo 2015; Resp.1/I1; internal regulation Tlaxcala s.a.; Resp.2/I1; Resp.3/I1; internal regulation Oaxaca 2011; Resp.4/I1)

\section{Results and discussion}

\section{Market and PGS organisation}

As is typical for Mexican PGS initiatives (Nelson et al. 2010, 2016), the PGS of case study markets were managed by their certification committees run at local market level [hereinafter referred to as Participatory Certification Committee (PCC)]. PCCs were embedded in a broader organisational structure, constituted by the respective market coordination, the respective General Assembly and various other working committees specific to each case. The General Assembly was the central decision-making body in each case, where issues relevant to the respective market and the PGS were regularly discussed. Each stand had a vote, mirroring the ideal of collective decision-making in PGS (IFOAM 2007). According to Papaoikonomou and Ginieis (2017), collective decision-making is important for decentralising information flows and avoiding concentration of information with the PCC and can lead to "a greater sense of collective empowerment" (Papaoikonomou and Ginieis 2017, p. 61). Other working committees (Fig. 1) were responsible for organising collective marketing and other collective activities.

Training and other collective activities, such as collective marketing, savings systems or seed banks, are an important element in many PGS (Bouagnimbeck 2014; Home et al. 2017; Nelson et al. 2016). In Oaxaca, no activities other than marketing and certification of products were organised. In Chapingo and Tlaxcala, activities 
Table 2 Actor groups other than producers and their role within the markets and their PGS at the time of data collection ([market concerned]; source: Resp.1/I1; Resp.2/I1; Resp.4/I1; Resp.8/I1, I4; internal document Chapingo 2016)

\begin{tabular}{|c|c|c|}
\hline Actor group & Contribution to/role within the market and PGS [market] & \\
\hline University & $\begin{array}{l}\text { Owner of the marketplace, provision of building free of charge } \\
\text { Owner of large part of market infrastructure (tables, chairs, etc.), provision free of charge }\end{array}$ & [A] \\
\hline NGO (s) & Offer of training, workshops, advisory & [B] \\
\hline Local municipality & Owner of the marketplace, provision of place free of charge & [B] \\
\hline Regional government & $\begin{array}{l}\text { Promotion (weekly announcement on regional radio station and weekly radio programme of producer organi- } \\
\text { sation on local radio station) }\end{array}$ & [B] \\
\hline TPC agency affiliates & $\begin{array}{l}\text { Occasional ongoing consultancy for PCC members if needed but no direct involvement in operation of the } \\
\text { PGS }\end{array}$ & [C] \\
\hline $\begin{array}{l}\text { Other local institutional } \\
\text { actors (e.g., parish) }\end{array}$ & Owner of the marketplace, provision of site free of charge & [C] \\
\hline Other local individual actors & e.g., employed park guards and garbage collectors & [C] \\
\hline
\end{tabular}

$A$ Chapingo, $B$ Tlaxcala, $C$ Oaxaca

included the organisation of events in the marketplace (e.g., festivities, workshops for consumers in Chapingo etc.) and the participation of producers in events such as organic fairs. In Tlaxcala, producers had started to manage a common savings fund to establish a common loans system (internal regulation Chapingo 2015; internal regulation Tlaxcala s.a.; Resp.1/I1; Resp.2/I1; Resp.4/ I1). According to Bellante (2017, p. 125), these activities represent "innovative solidarity practices" that encourage mutual support between producers and are important benefits of PGS participation. Home et al. (2017) argue similarly and highlight the type of interactions between group members as a distinctive characteristic of PGS. Therefore, the social processes in which group members engage are paramount for defining the system (Home et al. 2017). By fostering social cohesion, social processes such as knowledge exchange and joint training activities can positively influence PGS sustainability (Home et al. 2017). Social cohesion is related to those interactions and relations between actors involved in participatory processes that depict the glue holding these actors together (Idrissou et al. 2011) and nurture collective wellbeing (Kearns and Forrest 2000), and is linked to strong social relations and the absence of hidden conflicts (Kawachi and Berkman 2014) and disruptive behaviours (Kearns and Forrest 2000). It is also associated with levels of trust among actors (Idrissou et al. 2011; Kawachi and Berkman 2014) and is believed to be fostered through participation in joint activities (Idrissou et al. 2011). The above-mentioned social processes practised in PGS can therefore help strengthen relationships and build trust between PGS members and positively affect the unity of a PGS group (Home et al. 2017). The importance of a broader commitment to the market, transcending its economic dimension, was also emphasised as a key factor in the sustainability of the market and PGS by one respondent in Tlaxcala:
"The most important thing is to ensure that all of us who are part of the market do not only come for the economic part, in other words, to sell our products, but that we simultaneously try to strengthen social processes. For me, this is crucial. It's the most valuable part of everything here" (Resp.2/I1).

Other than the producers, consumers, university staff, NGOs, extension services and local governments are often involved in PGS development and operation (Bouagnimbeck 2014; May 2008). Home et al. (2017) claim that PGS are commonly managed by NGOs or producer associations and that producers' involvement in PGS is limited in practice. In the three case study markets, all the working committees, including the PCCs, were comprised exclusively of producers at the time of data collection. Other stakeholders were not involved in managing the certification process, but engaged in the PGS in terms of resource or knowledge provision (Table 2), thus assuming an important role in the maintenance and sustainability of PGS (Nelson et al. 2010; Nigh and González Cabañas 2015; Reyes Gómez 2010).

\section{Functionality of the certification process}

Certification processes resembled the one outlined by Nelson et al. (2016) and described for Chapingo Organic Market by Nelson et al. (2010). In all three markets, it included the following steps (Resp.1/I1; internal regulation Chapingo 2015; Resp.2/I1; Resp.3/I1; Resp.4/I1; internal regulation Oaxaca 2010):

1. submission of application for certification and membership by a producer wanting to join the market;

2. analysis of application and information provided by the producer;

3. visit of production site(s) and/or processing unit(s); 
4. analysis of information gathered during visit, elaboration of final report and certification decision; and

5. regular monitoring visits for producers who received a positive decision and joined the market.

This mirrored the markets' engagement with the Network in the past and the fact that Chapingo's process has been suggested as a model for other Network markets (Gómez 2013; Nelson et al. 2010). Despite its important role in the past and although former support from the Network was reported in all three markets, no relevant role of the Network during the time of data collection and no evidence for the Network's operation as reported by Nelson et al. (2016) could be identified. These findings may be specific to the studied markets and influenced by the sampling of interview partners. Other markets may be interlinked differently and talking to different people with different ties to (other) PGS initiatives may have delivered a different picture of PGS operation at a national level. The findings may also mirror the wider impacts of limited resources for sustaining the Network's work (Nelson et al. 2016). Therefore, the role of the Network in the case study markets will not be discussed further.

In all three markets the PCC was responsible for carrying out the certification process. In Chapingo, other market producers and consumers were free to participate in farm visits (Resp.1/I1), and in Tlaxcala consumers were invited as well (Resp.2/I1). The ongoing participation of consumers in the PCC was an aim in both markets, however this could not be achieved (Resp.1/I1; Resp.3/I1). Problems in establishing a multi-stakeholder PCC involving consumers have also been reported by Nelson (2012). In Oaxaca, the approach to consumer involvement was different, reflected by the market coordinator's reaction when asked about consumer participation: "No, no. Because, what we are doing is internal control" (Resp.4/I1). This somewhat contradicts the PGS ideal of active consumer participation (Bouagnimbeck 2014; IFOAM 2007). However, some producers arranged farm visits for consumers that were not related to the certification process (Resp.4/I1). These visits, as with regular certification visits, workshops and festivities in the marketplace and intense conversations between producers and consumers noticed on market days, represent important sharing events that can foster a reconnection between producers and their customers and are common in other types of LFS as well (Feagan and Henderson 2009; Flora and Bregendahl 2012; Nost 2014; Papaoikonomou and Ginieis 2017; Thompson and Coskuner-Balli 2007).

\section{Status of PGS implementation}

As PGS aim to make certification cheaper and more appropriate to the realities of being a smallholder farmer, certification in most PGS is based on voluntary work, making PGS
Table 3 Frequency of monitoring visits stipulated and share of producer survey respondents visited in 2015, 2014 and before

\begin{tabular}{lllll}
\hline & \multicolumn{2}{l}{ Market } & \multirow{2}{*}{ Total } \\
\cline { 2 - 4 } Survey item & $\mathrm{A}$ & $\mathrm{B}$ & $\mathrm{C}$ & \\
\hline $\mathrm{n}$ & 22 & 15 & 23 & 60 \\
$\mathrm{f}^{\mathrm{a}}$ & 19 & 14 & 18 & 51 \\
Frequency of visits stipulated & annual & 2 -yearly & annual & - \\
Visited in 2015 (\%) & 47.4 & 21.4 & 61.1 & 45.1 \\
Visited in 2014 (\%) & 36.8 & 71.4 & 22.2 & 41.2 \\
Visited neither in 2015 nor 2014 & 15.8 & 7.1 & 16.7 & 13.7 \\
$\quad(\%)$ & & & & \\
\hline
\end{tabular}

$A$ Chapingo, $B$ Tlaxcala, $C$ Oaxaca; $100 \%=\mathrm{n}$

${ }^{\mathrm{a}}$ Question not applicable for 9 respondents; $100 \%=\mathrm{f}$

highly dependent on members' voluntarily donated time (Bouagnimbeck 2014; Fonseca 2004; Nelson et al. 2010). Achieving sufficient, continuous producer participation is a challenge in PGS that is associated with a lack of continuity of and consistency in the certification process and problems in further developing the PGS (Bellante 2017; Bouagnimbeck 2014; Fonseca 2004; Nelson et al. 2010). As the PGS in all three markets were operated exclusively by producers, it is relevant to look at the status of PGS implementation regarding the continuity of the certification process and levels of producer participation.

\section{Continuity of the certification process}

Eighty per cent of producer survey respondents were certified through their markets' PGS $(\mathrm{A} / \mathrm{B} / \mathrm{C}=91 \% / 93 \% / 83 \%)$ and ought to have been receiving regular monitoring visits. Survey results revealed gaps regarding the continuity of the certification process (Table 3 ).

This mirrored the problems of continuously carrying out monitoring visits (Nelson et al. 2010) and implementing the PGS, especially in PGS operated exclusively by producers (Bellante 2017) reported in the literature.

In Chapingo, gaps in the certification process were mirrored by producers' evaluation of the certification process. The median evaluation of the process as currently practised on a scale from 1 (very bad) to 5 (very good) was 3 and significantly lower than in Tlaxcala $(\mathrm{mdn}=4$; Mann-Whitney $\mathrm{U}$ test, $\mathrm{U}=62.5, \mathrm{Z}=-3.135, \mathrm{p}=0.002, \mathrm{n}=35$ ) and in Oaxaca $(m d n=4$; Mann-Whitney $U$ test, $U=66, Z=-4.260$, $\mathrm{p}=0.000, \mathrm{n}=43$ ). In Oaxaca, increased continuity and more serious implementation of the certification process was the suggestion most frequently made by survey respondents (21.7\%) for improving the PGS.

Other findings suggested conflicts among producers as the main explanation for these gaps in Chapingo and time 
Table 4 Producer survey respondents' participation in Participatory Certification Committees (PCC) and farm visits

\begin{tabular}{|c|c|c|c|c|}
\hline \multirow[b]{2}{*}{ Survey item } & \multicolumn{3}{|c|}{ Market } & \multirow[t]{2}{*}{ Total } \\
\hline & A & $\mathrm{B}$ & $\mathrm{C}$ & \\
\hline $\mathrm{n}$ & 22 & 15 & 23 & 60 \\
\hline Participated in PCC since joining the market (\%) & 54.5 & 46.7 & 52.2 & 51.7 \\
\hline Participated in farm visits since joining the market (\%) & 77.3 & 60 & 56.5 & 65 \\
\hline Participated in PCC in $2015(\%)$ & 31.8 & 13.3 & 13 & 20 \\
\hline Participated in farm visits in 2015 (\%) & 22.7 & 20 & 13 & 18.3 \\
\hline $\begin{array}{l}\text { Not participated in } \mathrm{PCC}^{\mathrm{a}} \text { but in farm visits since joining the } \\
\text { market }(\%)\end{array}$ & 50 & 25 & 9.1 & 27.6 \\
\hline
\end{tabular}

$A$ Chapingo, $B$ Tlaxcala, $C$ Oaxaca; $100 \%=\mathrm{n}$

a $\mathrm{A} / \mathrm{B} / \mathrm{C} /$ Total $=10 / 8 / 11 / 29$; question not applicable for 31 respondents; $100 \%=\mathrm{f}$ constraints as an additional impact. The findings thus partly reflected the main challenges reported (Bellante 2017; Nelson et al. 2010). They further suggest that these underlying reasons were specifically mentioned because the PGS were operated exclusively by producers. The partiality of producers and conflict avoidance also influenced the degree of sincerity in PGS implementation.

\section{Producer participation}

Most survey respondents (51.7\%) had participated in the PCC and 65\% in farm visits since they joined the market (Table 4).

Levels of producer participation were thus lower than those reported by Nelson (2012; $46 \%$ of respondents volunteering in PCC at time of data collection), were comparable to those reported by IFOAM (2013; $45 \%$ having volunteered in PCC since joining the market) and were higher than those reported by Gómez (2013; 8.3\% volunteering in PCC; $11 \%$ having volunteered in PCC since joining the market). Results also differed between markets and in Oaxaca, for example, participation in farm visits focused more on PCC members.

The three main reasons indicated by producer survey respondents for not participating in the PCC partly reflected the factors hindering producer participation reported in the literature (Bellante 2017; Bouagnimbeck 2014; Fonseca 2004; Home et al. 2017; Nelson et al. 2010, 2016) (Fig. 2).

\section{Challenges in producer-led PGS initiatives}

\section{Time constraints}

The survey results partly reflected time constraints as a factor hindering producer involvement in PGS (Fig. 2). Although not mentioned by any of the survey respondents, time constraints influenced the continuity of the certification process in Tlaxcala. The frequency of monitoring visits had recently been changed to 2-yearly intervals for two main reasons: to give producers time to implement the recommendations for improvement made by the $\mathrm{PCC}$ during farm visits-mirroring the "fostering conversion rationale" of PGS (Coscarello and Rodríguez-Labajos 2015) — and to account for the time constraints of PCC members:

It [the certification process] is not that continuous because the certification work requires a lot of time. If we fully dedicate ourselves to certifying, we ourselves can't produce anymore (Resp.3/I1).

In particular the relationship between time and the effort required to dedicate themselves to PGS operation and the rewards that actors get in return seems to complicate PGS participation (Velleda Caldas and Sacco dos and Anjos 2014). Achieving sufficient PGS participation is particularly difficult due to the lack of economic rewards for the dedicated time and related opportunity costs (Bouagnimbeck 2014; Velleda Caldas and Sacco dos Anjos 2014). Opportunity costs were also emphasised by one respondent

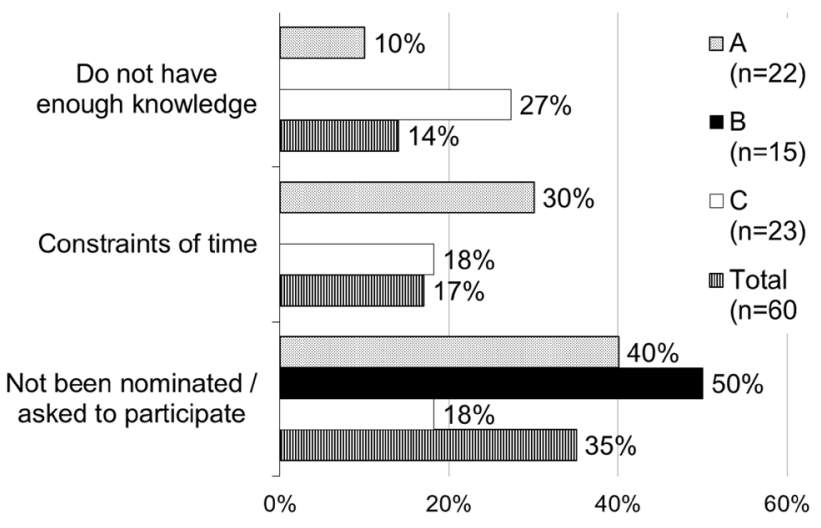

Fig. 2 Three main reasons for not participating in the Participatory Certification Committee (PCC) indicated by producer survey respondents (A Chapingo, B Tlaxcala, C Oaxaca; single-response option, $\mathrm{n}=60$, question not applicable for 31 respondents, $100 \%$ total $\mathrm{A} / \mathrm{B} / \mathrm{C}=29 / 10 / 8 / 11$ ) 
in Chapingo as a reason for not participating in the $\mathrm{PCC}$ or in farm visits:

I had other obligations. (...) I can't commit to participating in the committee, knowing that if I have other things to do and other obligations, for example, to sell my products at some [other] place, that I won't participate in the committee because there [in that other place] I earn more (Resp.7/I1).

The market's coordinator considered opportunity costs a hindering factor for participation, especially for producers who were economically worse off, and emphasised the importance of mechanisms to mitigate this effect for longterm PGS sustainability:

(...) I think that those in the PCC have to be provided with the conditions needed, for example their expenses. I would like to see that perhaps they receive some payment. Because sometimes they lose a whole day, and unfortunately sometimes it is people who don't have much money and they have to work. But if they go and certify colleagues they can't go to work or do things for their own needs. Therefore, I think that this could be a solution (Resp.1/I1).

Such a way of proceeding was however a matter of controversy with university affiliates because it was argued that this would convert the PCC into a TPC body, an issue that has also been highlighted by Home et al. (2017).

Material incentives are commonly used to facilitate the participation of local actors in CPR management (d'Adda 2011; Gurney et al. 2016; Idrissou et al. 2011; Vollan 2008). However, providing external (material) incentives can have detrimental effects, as externally provided incentives may replace the actors' intrinsic motivation for participating. Voluntary collective action is not nurtured (Vollan 2008). Nonmaterial incentive mechanisms (e.g., priming on desired behaviour) may show similar effects but to a lower degree (d'Adda 2011). However, care should be taken when designing a strategy for encouraging actor participation and deciding whether to set incentives or not, which ones to set and how (Gurney et al. 2016).

If economic remuneration for PCC members is considered a viable solution for compensating invested time, the question of financing arises, especially if external funds are unavailable and financing the PGS is already challenging (Fonseca 2004; Nelson et al. 2010). At the time of data collection PGS certification costs were paid by the producers' weekly fees and in all three markets exclusively refunded expenses for farm visits (e.g., fuel, bus tickets, accommodation) (Resp.1/I1; Resp.3/I1; Resp.4/I1). Forty-three per cent of producer survey respondents evaluated the costs paid for certification as very low or low and $57.1 \%$ as regular. The median on a scale from 1 (very low) to 5 (very high) was 3 (mdn $\mathrm{A} / \mathrm{B} / \mathrm{C}=3 / 3 / 4$ ). Thus it seems that additional fees to pay economic rewards for PCC members could be affordable for producers.

Another relevant issue that emerged in this context was determining the PGS certification costs and financial resources needed in the first place, which is not easy (IICA 2010) and apparently had not happened in any market. For example, in Chapingo and Tlaxcala, PCC members often paid their expenses themselves (Resp.1/I1; Resp.3/I1).

The involvement of universities or NGOs in administering and organising the certification process could address the producers' constraints of time and thus increase the continuity of the certification process (Bellante 2017; Bouagnimbeck 2014; Nelson et al. 2010, 2016). Nevertheless, considering the Network's history and that of another market visited where financial resources had ceased and the certification process was thus being paused (Resp.13/I1), it seems crucial that if PGS are to continue, there needs to be a financing plan, including an exit strategy from external funding and an evaluation of likely costs from the outset.

\section{Social conflicts}

Collective decision-making can decentralise information flows (Papaoikonomou and Ginieis 2017), but can also be a potential source of conflict. Consensus building, equal participation and sharing of responsibilities can be difficult to achieve (Nelson et al. 2010; Papaoikonomou and Ginieis 2017). Home et al. (2017) argue that participation in the PGS strengthens relationships among producers, but also implies challenges inherent to collective work such as personal differences and problems because it is not always possible to have an equal sharing of benefits and responsibilities. Disagreements between actors engaged in collective action activities and resulting conflicts are also reported for local CPR management groups (Ostrom 2015; Ravikumar et al. 2013; Van Laerhoven and Andersson 2013; Vedeld 2000). According to Nelson et al. (2010), biases in decisionmaking and conflicts in PGS primarily result from engaged actors being neither independent nor impartial and can be manifested among all the members of a multi-stakeholder PCC. However, as producers are those actors whose livelihoods are most dependent on the existence, reliability and outcomes of PGS, especially because any problem concerning one producer's production potentially endangers the market integrity in Mexican organic markets, reinforcing biases and tensions among producers (Nelson et al. 2010), it seems reasonable that these issues are more pronounced in PGS organised exclusively by producers.

According to Nelson et al. (2010), Home et al. (2017) and Escalona (2009), personal differences and conflicts can endanger PGS sustainability. This was also reflected in the present study's findings, with differences identified between 
the markets. Of those producers who had experienced problems in the market (45\%), 78\% mentioned problems related to personal differences among producers. In Chapingo it was $95 \%$ of producers who had experienced problems and in Tlaxcala $86 \%$. In Oaxaca, all the problems mentioned involved the marketplace and commercialisation of products or were on an individual level. Personal differences between producers and differences in opinions were key aspects in Chapingo and Tlaxcala, also emphasised by the respondents in key positions (Resp.1/I1; Resp.2/I1; Resp.3/I1). Respondents in Tlaxcala stressed personal differences as a normal implication of collective work:

Look, sometimes, within the market it is like within families. Within families nobody is perfect, there will always be little details, but we try to resolve them in a peaceful and consistent manner (Resp.2/I1).

In Chapingo, similar issues had resulted in the producer collective splitting into two groups. The certification process was no longer carried out at market level and it remained unclear to what extent it was implemented within the two groups. Some of those survey respondents who had not participated in the PCC or in farm visits, as "they had not been nominated or invited to do so" (Fig. 2), added that this was due, for example, to ongoing conflicts and that the former PCC had not invited other producers to participate (Resp.6/ I1), a lot of egoism and power struggles had emerged and that it was not possible to participate, especially for producers with lower levels of knowledge (Resp.7/I1).

Key challenges faced by the market were differences in opinions among producers in combination with a certain unwillingness to compromise and accept others' opinions, resultant conflicts and the division of the group (Resp.1/I1). This mirrored the findings from Argentinian peasant fairs, where the "ability to deal with possible conflicts arising [...] within peasants' organizations" (Cáceres 2005, p. 139) is a main challenge faced (Cáceres 2005). Nelson et al. (2016) conclude that "PGS relies upon, and simultaneously helps to strengthen, relationships of trust within food systems" (Nelson et al. 2016, p. 386). Relationships and trust among producers were critical issues. Relationships among producers were the aspect most frequently mentioned as a factor for future improvement in Chapingo, Tlaxcala and for the total sample (A/B/C/total: 50\%/40\%/0\%/28\%). In Chapingo, survey respondents' median evaluation of the relationship among producers on a scale from 1 (very bad) to 5 (very good) was 3 (regular), and statistically significantly lower than in Tlaxcala $(m d n=4$; Mann-Whitney $U$ test, $U=28$, $\mathrm{Z}=-4.431, \mathrm{p}=0.000, \mathrm{n}=36)$ and Oaxaca $(\mathrm{mdn}=5$; MannWhitney $\mathrm{U}$ test, $\mathrm{U}=17.5, \mathrm{Z}=-5.470, \mathrm{p}=0.000, \mathrm{n}=44$ ). Twenty-eight per cent of respondents in Chapingo evaluated the relationship as bad or very bad, $62 \%$ as regular. When asked to indicate their trust in the organic quality of products sold as organic by their colleagues, several producers in Chapingo explained that their evaluation for the entire market collective would differ greatly from their evaluation for "their group". Some expressed high trust in products sold by members of "their group", but doubts about products sold by other producers.

Addressing relationships and trust among producers is especially relevant as, following the definition of social cohesion of Kawachi and Berkman (2014), levels of social cohesion within the producer collective in Chapingo were low. If social cohesion is considered the glue holding producers together (Idrissou et al. 2011), facilitating collective action, social control, respect of rules and trust among PGS members (Zanasi et al. 2009), adopting effective conflict management, re-establishing trust among producers and nurturing social cohesion are of considerable importance. Rapid access to low-cost conflict resolution mechanisms has also been postulated by Ostrom (2015) as a central element if collective CPR management is to succeed.

Causes of ongoing conflicts in Chapingo should be identified carefully so as not to be based on speculation. Nevertheless, some evidence of them emerged throughout the field stay.

Firstly, mutual accusations between the two groups indicated personal differences caused by diverse periods of membership at the market and different ways of dealing with formal and informal rules defined for the market and the PGS. Respondents frequently stressed that "the others" had joined the market only recently and tried to change the rules or that "the others", who partly had been participating at the market since its inauguration, perceived themselves as "the owners of the market" and were unwilling to partly transfer power. This reflects the findings of Idrissou et al. (2011), who found informal rules to be gradually co-created by stakeholders engaged in participatory processes and to potentially support social cohesion among them. Conflict may emerge when new stakeholders join the collective and start to challenge these rules (Idrissou et al. 2011). Conflicts seemed to have been reinforced when one part of the market collective put a new PGS regulation to the vote in the General Assembly, without giving others the possibility to give their opinions. Thus, although approved by most producers in the General Assembly, the new regulation was not accepted by one part of the market collective. This is reflective of Van Laerhoven and Andersson's (2013, p. 125) suggestion that, "[i]f and how a consensus is reached, depends on the rules chosen to come to that particular agreement". The said rules must be considered legitimate for the consensus reached to be accepted and conflicts avoided. The way the new regulation had been developed and approved was not considered legitimate either, nor were the content and rules defined considered acceptable by some producers. According to Van Laerhoven and Andersson (2013), 
this may also be caused by a lack of institutional arrangements to handle such situations, which, once consensus is reached, determine the existence and severity of conflicts (Van Laerhoven and Andersson 2013). The importance of defined rules in CPR management has also been recognised by Ostrom (2007), who argues that it is the rules applied for defining how a CPR is governed, by whom it is owned and used, that determine whether conflict emerges (Ostrom 2007).

Secondly, conflicts seemed to be related to producers' preferences for market participation. Some producers accused others of participating only for economic reasons and not sharing the market's initial vision. This seems reasonable as actors participating in collective action most likely have different individual preferences, creating potential for conflicts (Van Laerhoven and Andersson 2013) and "[c]onflict emerges from differences in values and world views, conflicting interests, and the uncertainty that surrounds various courses of action" (O'Leary and Bingham 2003 , p. 5). It is also consistent with a common set of values as one central dimension of social cohesion (Kearns and Forrest 2000, p. 996).

Thirdly, competition in the marketplace is an aspect worth considering. Nelson (2012) found competition between market members to cause distrust and suspicion between them. This raises the question of the extent to which producers being organised primarily through the market, and thus not only being colleagues and peers but competitors as well, increased the potential for conflict and distrust relative to, for example, farmers selling their products to the PGS for onward distribution to points of sale (Home et al. 2017).

However, if this issue is to be understood fully it requires further studies explicitly focusing on the relationships among producers and reasons for conflicts between them.

\section{Partiality and conflict avoidance}

Apart from manifest conflicts, the potential for conflicts impacts on the seriousness and continuity of PGS implementation, relating to producers' tendency to implement the certification process rather leniently to avoid conflict. To avoid conflict among producers, there were no consequences of non-compliance with applied production standards in Tlaxcala (Resp.3/I1). In Oaxaca, the market coordination in place had only started to implement sanctions. This had been avoided due to its potential to cause conflict (Resp.4/ I1). The market's coordinator was worried that, after resigning from his position, his colleagues "would go after [him]" (Resp.4/I1). One PCC member in Tlaxcala also perceived the conflict of interest of being a friend and assuming the role of "an inspector" when carrying out farm visits as challenging (Resp.3/I1). This mirrors findings of Bellante (2017) who found self-enforcement of rules potentially burdensome for relationships among producers and rules being more difficult to enforce in a PGS initiative managed exclusively by producers, relative to a multi-stakeholder setting. It is also in accordance with Nelson et al. (2010), who report producers' partiality in the certification process and their tendency to be biased being reflected in too lax or rather strict behaviour. According to Van Laerhoven and Andersson (2013), institutions-which in PGS relate to rules for production, compliance assessment, decision-making and non-compliance-can reduce collective action problems, particularly those related to commitment and enforcement (Van Laerhoven and Andersson 2013).

\section{The potential of multi-stakeholder settings}

The engagement of universities or NGOs can help compensate for a lack of producer and consumer participation in PGS (Bellante 2017; Bouagnimbeck 2014; Nelson et al. $2010,2016)$ and increase the continuity of the certification process. It has been argued that it can also support the trustworthiness and reliability of the process (Nelson et al. 2016). External (institutional) actors (e.g., NGOs, government agencies) are often important for conflict management and resolution in CPR management (Barnes and Van Laerhoven 2013; Black and Watson 2006). They may act similarly in PGS and, by assuming the role of brokers, reduce the potential for conflict among producers and mitigate the negative effects on PGS implementation. Nevertheless, for third-party engagement to be effective, the implementation of rules is necessary and perceived legitimacy is of paramount importance (Van Laerhoven and Andersson 2013).

The increased involvement of other stakeholders was an issue in all three markets. Survey respondents considered the engagement of various stakeholders to be important for the certification process to work. Participation of actors other than producers was suggested by one quarter of the respondents in Tlaxcala (26.7\%) as a means of improving the market. When asked to rank different actor groups corresponding to the importance of their participation in the certification process for it to function properly, from 1 (least important) to 5 (most important), consumers received the highest mean rank in Tlaxcala (4.71) and Oaxaca (4.13), followed by university staff in Tlaxcala (3.43) and producers in Oaxaca (3.83). In Chapingo, consumers were placed third (3.67) after producers (4.14) and university staff (3.95). In Tlaxcala, the collaboration of a university in the certification process in particular was considered important for increasing the reliability and legitimacy of the process and improving the PGS in the future (Resp.2/I1; Resp.3/I2).

Furthermore, some sort of regional or national entity overseeing PGS implementation at local level and endorsing locally taken decisions, thus increasing the legitimacy and reliability of the PGS (Bouagnimbeck 2014; Home et al. 
2017; IFOAM 2013; Nelson et al. 2016), may help to mitigate conflicts and decision-making biases. However, holding a national committee accountable for local PGS implementation across the country-previously a fundamental idea of the Network-may prove rather unfeasible and problematic in practice (Resp.8/I4).

As PGS are officially endorsed within the LPO and recognition before the national competent authority is needed to operate legally a PGS, the national competent authority could act as legitimating force, making local PGS more reliable, providing a baseline on which to build the PGS and reducing the biases and partiality of locally engaged actors.

\section{Legal recognition of PGS and implications at grassroots level}

Lack of official legal recognition as an organic certification system presents a challenge for many PGS initiatives. This mainly stems from the integrated approach of PGS towards certification and the combination of inspection and extension services (Meirelles 2003; Nelson et al. 2010), and results in problems in achieving organic market access and thus price premiums (May 2008; Meirelles 2003; Nelson et al. 2010), the impossibility of accessing possible subsidies (Torremocha Bouchet 2012b), uncertainty regarding the future of the PGS and difficulties for PGS expansion (Fonseca 2004). Official legal recognition is thus often considered key for PGS sustainability (Home et al. 2017). Endorsement of PGS in the LPO (2006) as a legal alternative to TPC for smallholders on the domestic market is therefore considered a major achievement of the Network, which contributed with fundamental lobbying to PGS endorsement (Nelson et al. 2010). Since April 2015, when the national guidelines for organic production (hereinafter referred to as the guidelines), which define requirements for PGS more comprehensively, fully came into force, certification - through TPC or PGS - is a legal requirement if products are to be labelled as organic. Local organic markets therefore need to comply with requirements for PGS certification defined within the LPO and the guidelines. As these findings show, this is a controversial requirement among actors engaged in these markets and can be burdensome, possibly even unachievable, especially for markets that do not have support from universities or NGOs for example.

According to the guidelines, markets need to have their PCC officially recognised by the national competent authority and submit several documents, including for example a PGS operation manual, documents to prove PCC members' experience of organic farming, a description of systems for supervision and farm records and management plans (SAGARPA 2014).

At the time of data collection, none of the case study markets' PCC had applied for legal recognition. Not many of the required documents were available. For example, the market in Oaxaca had no written regulation describing PGS operation. Although it was being developed, the market's coordinator emphasised time constraints as a hindering factor (Resp.4/I1), mirroring findings from other authors (Fonseca 2004; IFOAM 2013; Nelson et al. 2008, 2010). Already without documents such as farm records and management plans, $40 \%$ of survey respondents evaluated the paperwork required for PGS certification as high or very high, with a median of $3(\mathrm{mdn} \mathrm{A} / \mathrm{B} / \mathrm{C}=3 / 3 / 4)$, on a scale from 1 (very low) to 5 (very high), raising the question of if and how producers, especially in Oaxaca, would be able to complete the paperwork required for legal recognition.

Providing sufficient documentation is a general obstacle for legal PGS endorsement and it is hard to find equilibrium between a degree of documentation and regulation that makes the certification process transparent, while maintaining the system's flexible, unbureaucratic character (May 2008; Meirelles 2003). Some respondents considered complete documentation to be a major obstacle in achieving legal recognition for Mexican PGS initiatives.

In Chapingo, the university resumed its collaboration by the time that data collection was drawing to a close and established a new PGS regulation, aimed at fulfilling legal requirements and achieving legal recognition soon. Producers in Tlaxcala and Oaxaca had no institutional support for PGS operation, leaving some doubt as to how producers would be able to fulfil requirements in the future. On a national level, four markets had applied for legal recognition by the time data collection finished. None of them had yet achieved legal recognition, mainly due to insufficient documentation (Resp.11/I1).

The opinions of survey respondents and interview partners on PGS endorsement in the LPO and the requirement of legal recognition varied. Some producers in Chapingo emphasised it as important because "not everyone could claim to have a PGS in place and to produce organically" (Resp.9/I1) and considered it important for increasing PCCs' authority within the market, such as to implement sanctions (Resp.5/I1). The same respondent assumed that requirements could threaten many markets that lacked the necessary capacities and would be incapable of meeting legal requirements (Resp.5/I2). The recognition process as a prerequisite for selling PGS-certified products as organic generally seemed to be viewed positively, but also seen as difficult to achieve by many, such as due to missing farm records (Resp.10/I1). There was also evidence of some confusion among producers regarding the exact requirements for documentation (e.g., how to prove PCC members' experience of organic farming) (Resp.10/I1). Difficulties in meeting legal requirements were also stressed by Tlaxcala's market 
coordinator, in combination with reservations about engaging with the government:

"Within the law about certification there is a part which regulates that participatory certification can exist. But we also depend on the government. For example, they regulate the part about participatory certification, without having the slightest idea what it is all about, because they are not working on the field, they don't really know the work we are doing. And we have to comply with the standards they set. And this is really complicated" (Resp.2/I1).

Another respondent also stressed that some markets were rejecting the fact that the government was imposing its regulations on them and might refuse to apply for legal recognition (Resp.5/I2). He assumed that these markets would try to find different solutions (Resp.5/I2), such as emphasising product attributes other than organic quality for product labelling, a solution that has been suggested for PGS initiatives in countries where PGS are not yet legally recognised (Fonseca 2004; May 2008). This reflects the ongoing controversial discussions with the PGS movement on whether and how to regulate PGS (Fonseca 2004; Torremocha Bouchet 2012a; Torremocha Bouchet 2012b).

The fear that PGS may undergo the same changes once regulation is increased (Fonseca 2004; Torremocha Bouchet 2012a; Torremocha Bouchet 2012b) as organic certification in Europe during the 1990s was also expressed by one respondent (Resp.8/I5), connected to the problem that PCCs had to fulfil the same requirements as TPC bodies, although in contrast to TPC bodies they are not profitoriented (Resp.8/I4; Resp.12/1). One respondent stressed that TPC bodies could start to apply PGS, but "according to criteria set by them", emphasising the role of universities and "academic PCCs" in offering the services at better conditions for producers without experience (Resp.12/I1). This mirrors the importance of universities recognised in the literature.

When trying to marry legal recognition and ensure that regulation of PGS and bureaucratic processes are still bearable for actors at grass-roots level, it would seem worthwhile to consider the Brazilian organic legislation and the US National Organic Program (NOP). Apart from TPC and "formal" PGS, Brazilian organic legislation recognises a second, "informal" type of PGS, which is only valid for direct sale to consumers, but not concerned by legal registration (Meirelles 2010). The NOP in contrast exempts organic producers with less than US\$ 5000 gross annual income from agriculture from certification requirements (USDA 2016).

\section{Concluding remarks}

These findings revealed gaps regarding the implementation of the certification process, with the suggestion of underlying reasons being time constraints of and conflicts between producers. Conflicts of interest between PCC members and conflict avoidance affected PGS implementation. The challenges faced thus partly mirror the rationale behind the development of TPC put forward by its promoters.

The paper further demonstrates that opportunity costs of PCC participation can be a factor determining producer participation in the PCC and in the PGS, and that mechanisms to account for these opportunity costs and to mitigate disadvantageous effects of PGS participation (e.g., lost income due to voluntary work in the PGS) are important if producers' PGS participation is to be facilitated and PGS sustainability ensured. Other studies suggest that mechanisms to account for opportunity costs (e.g., economic remuneration) need to be chosen and adopted carefully against the backdrop of local specificities if intrinsic motivations are not to be replaced by external incentives. Furthermore, the development of a feasible, sustainable financing strategy for the certification process from the outset of the PGS, including these remuneration payments, is key.

Another important finding to emerge was that although conflicts between engaged actors may occur as a regular implication of collective work, personal conflicts, low levels of social cohesion and the lack of mechanisms to deal with arising conflicts can considerably endanger the durability of PGS. Mechanisms of conflict management or resolution, which are based on institutional arrangements perceived as legitimate and consider different individual preferences of the engaged actors, emerged as an important strategy for dealing with these problems. External (institutional) actors may assume an important role in this context. These actors have also been suggested by several authors as important in order to mitigate the time constraints of producers in PGS. The perceived legitimacy of their engagement needs to be guaranteed. However, more research is required to better understand group dynamics and social relations in PGS and their effects on PGS performance and sustainability.

Although the LPO has recognised PGS since 2006 and legal recognition before the national competent authority has been required since April 2015, it had not been achieved by any of the PGS initiatives studied when data for this paper was being collected. The requirements laid down by the law were perceived as burdensome and the question remains of whether and how PGS initiatives, especially those managed exclusively by producers, will be able to meet these requirements in future. The research presented in this paper further suggests that external (institutional) actors may assume an important role in PGS initiatives achieving legal recognition as well.

Acknowledgements The authors would like to thank all producers, consumers and other key informants who participated in the research and acknowledge Dr. Rita Schwentesius Rindermann, Dr. Manuel 
Table 5 List of respondents

\begin{tabular}{|c|c|c|c|c|}
\hline Abbr. & Interview & Role/type of actor & Date of interview & Type of interview \\
\hline Resp.1 & $\mathrm{I} 1$ & Market coordinator & December 2015 & Semi-structured \\
\hline Resp.2 & $\mathrm{I} 1$ & Market coordinator & December 2015 & Semi-structured \\
\hline \multirow[t]{2}{*}{ Resp.3 } & I1 & PCC member & December 2015 & Semi-structured \\
\hline & $\mathrm{I} 2$ & & December 2015 & Semi-structured \\
\hline Resp.4 & $\mathrm{I} 1$ & Market coordinator & November 2015 & Semi-structured \\
\hline \multirow[t]{2}{*}{ Resp.5 } & $\mathrm{I} 1$ & Market producer, former PCC member & December 2015 & Survey \\
\hline & $\mathrm{I} 2$ & Market producer & March 2016 & Informal \\
\hline Resp.6 & $\mathrm{I} 1$ & Market producer & December 2015 & Survey \\
\hline Resp.7 & I1 & Market producer & October 2015 & Survey pretest \\
\hline \multirow[t]{3}{*}{ Resp.8 } & I1 & Others $^{\mathrm{a}}$ & October 2015 & Informal \\
\hline & I4 & & January 2016 & Informal \\
\hline & I5 & & February 2016 & Meeting \\
\hline Resp.9 & $\mathrm{I} 1$ & Market producer, former PCC member & November 2015 & Survey \\
\hline Resp.10 & I1 & Market coordinator & March 2016 & Informal \\
\hline Resp.11 & $\mathrm{I} 1$ & Others $^{\mathrm{a}}$ & March 2016 & Semi-structured \\
\hline Resp.12 & I1 & Others $^{\mathrm{a}}$ & March 2016 & Semi-structured \\
\hline Resp.13 & $\mathrm{I} 1$ & Market coordinator & November 2015 & Informal \\
\hline
\end{tabular}

${ }^{a}$ To ensure the maximum anonymity of respondents, interview partners engaged with PGS in Mexico, other than producers and consumers, were summarised into one category and their role/position and the affiliated institution not specified further

Ángel Gómez Cruz and their team from CIIDRI, Chapingo University, without whom research presented would not have been possible. We further acknowledge the Center for International Relations at the University of Natural Resources and Life Sciences, Vienna for funding parts of the field research through a scholarship. Open access funding provided by University of Natural Resources and Life Sciences Vienna (BOKU).

Open Access This article is distributed under the terms of the Creative Commons Attribution 4.0 International License (http://creativecommons.org/licenses/by/4.0/), which permits unrestricted use, distribution, and reproduction in any medium, provided you give appropriate credit to the original author(s) and the source, provide a link to the Creative Commons license, and indicate if changes were made.

\section{Appendix}

See Table 5.

\section{References}

Andrade, M. P. 2015. Non-third party certification schemes. The case of Participatory Guarantee Systems in Ecuador. Master Thesis. Amsterdam: University of Amsterdam. http://repositorio.educacionsuperior.gob.ec/handle/28000/1954. Accessed 22 Feb 2017.

Barnes, C., and F. Van Laerhoven. 2013. Helping to self-help? External interventions to stimulate local collective action in Joint Forest Management, Maharashtra, India. International Forestry Review $15(1): 1-17$
Beck, N., and P. Walgenbach. 2003. ISO 9000 and formalization-How organizational contingencies affect organizational responses to institutional forces. Schmalenbach Business Review 55: 293-320.

Bellante, L. 2017. Building the local food movement in Chiapas, Mexico: Rationales, benefits, and limitations. Agriculture and Human Values 34 (1): 119-134.

Bernard, H. R. 2011. Research methods in anthropology: Qualitative and quantitative approaches, 5th ed. Plymouth: AltaMira Press.

Black, R., and E. Watson. 2006. Local community, legitimacy, and cultural authenticity in postconflict natural resource management: Ethiopia and Mozambique. Environment and Planning D: Society and Space 24(2): 263-282.

Bouagnimbeck, H. 2014. Global comparative study on interactions between social processes and Participatory Guarantee Systems. A best practice study for learning and development with case studies from Africa, Asia, Europe and Latin America. Bonn: International Federation of Organic Agriculture Movements (IFOAM).

Boza Martínez, S. 2013. Los Sistemas Participativos de Garantía en el fomento de los mercados locales de productos orgánicos. Polis [en línea] 34:1-11. http://0-dx.doi.org.innopac.up.ac.za/http://polis. revues.org/8718. Accessed 22 Feb 2017.

Bühl, A. 2016. SPSS 23: Einführung in die moderne Datenanalyse. 15th ed. Hallbergmoos: Pearson Deutschland GmbH.

Cáceres, D. 2005. Non-certified organic agriculture: An opportunity for resource-poor farmers? Outlook on Agriculture 34 (3): 135-140.

Coscarello, M., and B. Rodríguez-Labajos. 2015. Certificación 'de papel' o de relaciones humanas? Los sistemas de garantía participativa como iniciativas de soberanía alimentaria local. Ecología Política (49): 35-41.

d'Adda, G. 2011. Motivation crowding in environmental protection: Evidence from an artefactual field experiment. Ecological Economics 70 (11): 2083-2097.

Darnhofer, I. 2006. Organic farming between professionalisation and conventionalisation. The need for a more discerning view of farmer practices. Paper presented at Joint Organic Congress, 
Odense, Denmark, 2006. http://orgprints.org/7390. Accessed 22 Feb 2017.

DuPuis, E. M., and D. Goodman. 2005. Should we go "home" to eat?: Toward a reflexive politics of localism. Journal of Rural Studies 21 (3): 359-371.

Escalona, M.À. 2009. Los tianguis y mercados locales de alimentos ecológicos en México: Su papel en el consumo, la producción y la conservación de la biodiversidad y cultura. Doctoral Thesis, Departamento de Ciencias Sociales y Humanidades. Córdoba, Spain: Universidad de Córdoba. http://helvia.uco.es/xmlui/handle/10396/3516. Accessed 22 Feb 2017.

Feagan, R., and A. Henderson. 2009. Devon Acres CSA: Local struggles in a global food system. Agriculture and Human Values 26 (3): 203-217.

Flora, C. B., and C. Bregendahl. 2012. Collaborative communitysupported agriculture: Balancing community capitals for producers and consumers. International Journal of Sociology of Agriculture and Food 19 (3): 329-346.

Fonseca, M. F. 2004. Alternative Certification and a Network Conformity Assessment Approach. Bonn: International Federation of Organic Agriculture Movements (IFOAM). http://www. ifoam.org/sites/default/files/page/files/alternativecertificationandanetworkconformityassessmentapproach.pdf. Accessed 22 Feb 2017.

Fouilleux, E., and A. Loconto. 2017. Voluntary standards, certification, and accreditation in the global organic agriculture field: A tripartite model of techno-politics. Agriculture and Human Values 34 (1): 1-14.

Gómez, A. M. 2013. Mercados locales de productos orgânicos a partir de sistemas participativos de garantía, zona Centro estado de Veracruz. Master Thesis. Montecillo, Texcoco, Mexico: Colegio de Postgraduados Montecillo.

Gurney, G. G., J. E. Cinner, J. Sartin, R. L. Pressey, N. C. Ban, N. A. Marshall, and D. Prabuning. 2016. Participation in devolved commons management: Multiscale socioeconomic factors related to individuals' participation in community-based management of marine protected areas in Indonesia. Environmental Science and Policy 61: 212-220.

Hatanaka, M., C. Bain, and L. Busch. 2005. Third-party certication in the global agrifood system. Food Policy 30: 354-369.

Home, R., and E. Nelson. 2015. The role of Participatory Guarantee Systems for Food Security. In Feeding the people: Agroecology for nourishing the world and transforming the agri-food system, eds. A. Hilbeck, and B. Oehen, 26-29. Brussels: IFOAM EU Group.

Home, R., H. Bouagnimbeck, R. Ugas, M. Arbenz, and M. Stolze. 2017. Participatory guarantee systems: Organic certification to empower farmers and strengthen communities. Agroecology and Sustainable Food Systems 41: 1-20.

Idrissou, L., A. van Paassen, N. Aarts, and C. Leeuwis. 2011. From cohesion to conflict in participatory forest management: The case of Ouémé Supérieur and N'Dali (OSN) forests in Benin. Forest Policy and Economics 13 (7): 525-534.

IFOAM. 2007. Participatory Guarantee Systems. Shared Vision, Shared Ideals. Bonn, Germany: International Federation of Organic Agriculture Movements (IFOAM). http://www.ifoam. org/sites/default/files/page/files/ifoam_pgs_web.pdf. Accessed $21 \mathrm{Feb} 2017$.

IFOAM. 2008. Definition of Participatory Guarantee Systems. Bonn, Germany: International Federation of Organic Agriculture Movements (IFOAM). http://www.ifoam.bio/sites/default/files/pgs_definition_in_different_languages.pdf. Accessed: 21 Feb 2017.

IFOAM. 2013. Sistemas Participativos de Garantìa. Estudios de caso en América Latina. Bonn: International Federation of Organic Agriculture Movements (IFOAM).
IFOAM. 2016a. PGS Maps: Global Map of PGS initiatives. http:// www.ifoam.bio/en/global-online-pgs-database. Accessed $21 \mathrm{Feb}$ 2017.

IFOAM. 2016b. PGS-Maps: PGS Statistic Map-Updates from 2015 Global PGS Survey. http://www.ifoam.bio/en/pgs-maps. Accessed $21 \mathrm{Feb} 2017$.

IICA. 2010. Sistemas de garantía para productos orgánicos en mercados locales y nacionales. San José: Inter-American Institute for Cooperation in Agriculture (IICA).

Janssen, J., and W. Laatz. 2010. Statistische Datenanalyse mit SPSS. Eine anwendungsorientierte Einführung in das Basissystem und das Modul Exakte Tests. 7th ed. Berlin, Heidelberg: Springer.

Källander, I. 2008. Participatory Guarantee Systems-PGS. Stockholm: Swedish Society for Nature Conservation.

Kawachi, I., and L. F. Berkman. 2014. Social cohesion, social capital, and health. In Social epidemiology, eds. L. F. Berkman, I. Kawachi, and M. Glymour, 290-320. New York: Oxford University Press.

Kearns, A., and R. Forrest. 2000. Social cohesion and multilevel urban governance. Urban Studies 37 (5-6): 995-1017.

Kirchner, C. 2014. Participatory Guarantee Systems (PGS). How PGS can intensify knowledge exchange between farmers. Paper presented at IFOAM Organic World Congress 2014, Istanbul, Turkey.

May, C. 2008. PGS Guidelines-How Participatory Guarantee Systems can develop and function. Bonn, Germany: International Federation of Organic Agriculture Movements (IFOAM). http://www. ifoam.org/sites/default/files/page/files/pgs_guidelines_en_web. pdf. Accessed 21 Feb 2017.

Meirelles, L. 2003. Certification of Organic Products. Brazil: Centro Ecològico Ipê. http://www.google.at/url?sa=t\&rct=j\&q=\&esrc $=\mathrm{s} \&$ source $=$ web $\& \mathrm{~cd}=3 \& \mathrm{ved}=0 \mathrm{CEIQFjAC} \& u \mathrm{ul}=\mathrm{http} \% 3 \mathrm{~A} \% 2$ F\%2Fwww.centroecologico.org.br\%2Fcertificacao_download. php\%3Fid_pdfcertificacao\%3D41\%26tipo\%3Dpdf\&ei=SzQ5U_2 KIrOO7QaX1YCQDg\&usg=AFQjCNELaZN6pN_CQwgZ7LRT1 TzVujHVkg\&bvm=bv.63808443,d.ZGU. Accessed 21 Feb 2017.

Meirelles, L. 2010. Regulation of the Participatory Guarantee Systems in Brazil - a case study. Bonn, Germany: International Federation of Organic Agriculture Movements (IFOAM). http://www.ifoam. bio/sites/default/files/page/files/regulationofpgsinbrazil-casestudy. pdf. Accessed 21 Feb 2017.

Morgan, K., T. Marsden, and J. Murdoch. 2006. Worlds of food: Place, power, and provenance in the food chain. Oxford: Oxford University Press.

Nelson, E. 2012. Re-imagining Food Systems in Mexico: A Case Study from the Network of Local Organic Markets. Doctoral Thesis. Guelph: University of Guelph.

Nelson, E., L. Gómez Tovar, R. Schwentesius Rindermann, and M.Á. Gómez Cruz. 2008. Growing a local organic movement: The Mexican Network of Organic Markets. LEISA Magazine 24: 24-27.

Nelson, E., L. Gómez Tovar, and R. Schwentesius Rindermann, and M.Á. Gómez Cruz. 2010. Participatory organic certification in Mexico: An alternative approach to maintaining the integrity of the organic label. Agriculture and Human Values (27): 227-237.

Nelson, E., L. Gómez Tovar, E. Gueguen, S. Humphries, K. Landman, and R. Schwentesius Rindermann 2016. Participatory Guarantee Systems and the re-imagining of Mexico's organic sector. Agriculture and Human Values 33(2): 373-388.

Nigh, R., and A. A. González Cabañas. 2015. Reflexive Consumer Markets as Opportunities for New Peasant Farmers in Mexico and France: Constructing Food Sovereignty Through Alternative Food Networks. Agroecology and Sustainable Food Systems 39 (3): 317-341.

Nost, E. 2014. Scaling-up local foods: Commodity practice in community supported agriculture (CSA). Journal of Rural Studies 34: $152-160$. 
O'Leary, R., and L. B. Bingham. 2003. The promise and performance of environmental conflict resolution. Washington DC: Resources for the Future.

Ostrom, E. 2007. A diagnostic approach for going beyond panaceas. Proceedings of the National Academy of Sciences 104(39): 15181-15187.

Ostrom, E. 2015. Governing the commons. The evolution of institutions for collective action. Cambridge: Cambridge University Press.

Padel, S., J. Vine, B. Huber, M. Stolze, L. M. Jespersen, E. Rüegg, F. Meinshausen, A. Puliga, A. Compagnioni, and S. R. Belliere. 2010. The European regulatory framework and its implementation in influencing organic inspection and certification systems in the EU. Organic eprints. http://orgprints.org/18359/. Accessed 22 Feb 2017.

Papaoikonomou, E., and M. Ginieis. 2017. Putting the farmer's face on food: Governance and the producer-consumer relationship in local food systems. Agriculture and Human Values 34: 53-67.

Puri, R. K. 2011. Participant observation. In Conducting Research in Conservation: Social Science Methods and Practice, eds. H. Newing, C. M. Eagle, R.K. Puri, and C.W. Watson. Abingdon, Oxan: Routledge.

Ravikumar, A., K. Andersson, and A. M. Larson. 2013. Decentralization and forest-related conflicts in Latin America. Forest Policy and Economics 33: 80-86.

Raynolds, L. T. 2004. The globalization of organic agro-food networks. World Development 32 (5): 725-743.

Renting, H., M. Schermer, and A. Rossi. 2012. Building food democracy: Exploring civic food networks and newly emerging forms of food citizenship. International Journal of Sociology of Agriculture and Food 19 (3): 289-307.

Reyes Gómez, A. C. 2010. Red Comida Sana y Cercana: Construyendo Nuevas Estrategias de Comercialización y Producción. Master Thesis. San Cristóbal de las Casas, Chiapas, Mexico: El Colegio de la Frontera Sur.

Sacchi, G., V. Caputo, and R. Nayga. 2015. Alternative labeling programs and purchasing behavior toward organic foods: The case of the participatory guarantee systems in Brazil. Sustainability 7 (6): 7397-7416.

SAGARPA. 2014. Agreement through which the Guidelines for the organic operation of the agricultural and livestock activities are made public. Secretaría de Agricultura, Ganadería, Desarrollo Rural, Pesca y Alimentación de México (SAGARPA).

Saldaña, J. 2013. The coding manual for qualitative researchers. $2 \mathrm{nd}$ ed. Los Angeles/London/New Delhi/Singapore/Washington DC: Sage Publications Ltd.

Schulze, H., F. Albersmeier, A. Spiller, and G. Jahn. 2006. Audit risk factors in certification-How can risk-oriented audits improve the quality of certification standards? Paper presented at 98th EAAE Seminar 'Marketing Dynamics within the Global Trading System: New Perspectives', June 29-July 2, 2006, Chania, Crete, Greece. http://ageconsearch.umn.edu/bitstream/10108/1/sp06sc05.pdf. Accessed Mar 242017.

Sligh, M., and T. Cierpka. 2007. Organic values. In Organic farming. An international history, ed. W. Lockeretz, 30-39. Wallingford: CAB International.
Thompson, C. J., and G. Coskuner-Balli. 2007. Enchanting ethical consumerism the case of community supported agriculture. Journal of Consumer Culture 7 (3): 275-303.

Torremocha Bouchet, E. 2012a. Los sistemas participativos de garantía. Herramienta para la definición de estrategias agroecológicas. Sevilla: Universidad Internacional de Andalucía.

Torremocha Bouchet, E. 2012b. Sistemas Participativos de Garantía. Una herramienta clave para la Soberanía Alimentaria. Mundubat. http://www.redcimas.org/wordpress/wp-content/uploads/2012/10/ sistemas_participativos_degarantia.pdf. Accessed 22 Feb 2017.

USDA. 2016. Organic production documentation. United States Department of Agriculture-Economic Research Service. https:// www.ers.usda.gov/data-products/organic-production/documentation.aspx. Accessed Mar 232017.

Van Laerhoven, F., and K. P. Andersson. 2013. The virtue of conflict: An institutional approach to the study of conflict in community forest governance. International Forestry Review 15 (1): 122-135.

Vedeld, T. 2000. Village politics: Heterogeneity, leadership and collective action. The Journal of Development Studies 36 (5): 105-134.

Velleda Caldas, N., and F. Sacco dos Anjos. 2014a. Agricultura familiar y sistemas participativos de garantía en el sur de Brasil. In Agricultura Familiar en España ANUARIO 2014, D. Juste, ed. et al. Agricultura Familiar en España ANUARIO 2014, Madrid: Fundación de estudios rurales unión de pequeños agricultores y ganaderos.

Velleda Caldas, N., F. Sacco dos Anjos, and C. Lozano Cabedo. 2014b. Obstáculos hacia la implantación de un sistema participativo de garantía en Andalucía. Revista de la Red Iberoamericana de Economía Ecológica 22: 53-68.

Vogl, C. R., and P. Axmann. 2016. Regelungsmechanismen im System Ökologischer Landbau. In Ökologischer Landbau-Grundlagen, Wissensstand und Herausforderungen, ed. B. Freyer, 124-145. Stuttgart: UTB.

Vogl, C. R., L. Kilcher, and H. Schmidt. 2005. Are standards and regulations of organic farming moving away from small farmers' knowledge? Journal of Sustainable Agriculture 26 (1): 5-26.

Vollan, B. 2008. Socio-ecological explanations for crowding-out effects from economic field experiments in southern Africa. Ecological Economics 67 (4): 560-573.

Yin, R. K. 1994. Case study research-design and methods. 2 ed. Thousand Oaks: SAGE Publications.

Zanasi, C., P. Venturi, M. Setti, and C. Rota. 2009. Participative organic certification, trust and local rural communities development: The Case of Rede Ecovida. New Medit 2: 56-64.

Sonja Kaufmann has an MSc degree in Organic Farming from the University of Natural Resources and Life Sciences, Vienna, Austria. Master thesis about Participatory Guarantee Systems in Mexico.

Christian R. Vogl is Head of the Working Group Knowledge Systems and Innovation and Deputy Head of the Department of Sustainable Agricultural Systems at the University of Natural Resources and Life Sciences, Vienna. University professor for Organic Farming. 